\title{
Synaptic Therapy in Alzheimer's Disease: A CREB-centric Approach
}

\author{
Andrew F. Teich • Russell E. Nicholls • Daniela Puzzo • \\ Jole Fiorito • Rosa Purgatorio • Mauro Fa' • Ottavio Arancio
}

Published online: 10 January 2015

(C) The American Society for Experimental NeuroTherapeutics, Inc. 2015

\begin{abstract}
Therapeutic attempts to cure Alzheimer's disease (AD) have failed, and new strategies are desperately needed. Motivated by this reality, many laboratories (including our own) have focused on synaptic dysfunction in AD because synaptic changes are highly correlated with the severity of clinical dementia. In particular, memory formation is accompanied by altered synaptic strength, and this phenomenon (and its dysfunction in $\mathrm{AD}$ ) has been a recent focus for many laboratories. The molecule cyclic adenosine monophosphate response element-binding protein (CREB) is at a central converging point of pathways and mechanisms activated during the processes of synaptic strengthening and memory formation, as CREB phosphorylation leads to transcription of memory-associated genes. Disruption of these mechanisms in $\mathrm{AD}$ results in a reduction of CREB activation with accompanying memory impairment. Thus, it is likely that strategies aimed at these mechanisms will lead to future therapies for $\mathrm{AD}$. In this review, we will summarize literature that investigates 5 possible therapeutic pathways for rescuing synaptic dysfunction in AD: 4 enzymatic pathways that lead to CREB phosphorylation (the cyclic adenosine monophosphate cascade, the serine/threonine kinases extracellular regulated kinases 1 and 2, the nitric oxide cascade, and the calpains), as well as histone acetyltransferases and histone deacetylases (2 enzymes that regulate the histone acetylation necessary for gene transcription).
\end{abstract}

\footnotetext{
A. F. Teich · R. E. Nicholls · J. Fiorito · R. Purgatorio · M. Fa' • O. Arancio $(\bowtie)$

Department of Pathology \& Cell Biology, Taub Institute for Research on Alzheimer's Disease and the Aging Brain, Columbia University, New York, NY 10032, USA

e-mail: oa1@columbia.edu
}

D. Puzzo

Department of Bio-Medical Sciences, Section of Physiology, University of Catania, Catania 95125, Italy
Keywords cAMP/PKA/CREB cascade $\cdot$ Calpains $\cdot$ NO cascade $\cdot$ HAT $\cdot$ HDAC $\cdot$ ERK1/2 MAP kinase pathway

\section{Introduction}

For years the debate over the causes of Alzheimer's disease (AD) was dominated by 2 major neuropathologic hallmarks: amyloid plaques, consisting mostly of extracellular deposits of amyloid-beta $(A \beta)$ peptides, a downstream product of the processing of the larger amyloid precursor protein (APP); and neurofibrillary tangles (NFTs), consisting mostly of intraneuronal accumulations of hyperphosphorylated tau protein. However, neither the degree of amyloid plaque nor NFT pathology are as highly correlated with the severity of clinical dementia as synaptic pathology [1]. Both pathogenic $A \beta$ and tau assemblies could, in turn, alter the mechanisms underlying the excitatory response at single synapses producing synaptic dysfunction before synapse loss [2]. Faltering of the synapses at early stages of the disease would underlie subtle amnesic problems in patients with AD. These events would open up a temporal frame during which it might be still possible to intervene therapeutically before any irreversible damage has occurred. Because of this possibility our laboratories and many others have focused their research on the identification of the molecular mechanisms responsible for synaptic dysfunction, in particular mechanisms that impair long-term potentiation (LTP), a type of synaptic strengthening that is likely to underlie learning and memory. A particularly interesting study that developed this idea came from the laboratories of Lloyd Green and Michael Shelanski at Columbia University, where $A \beta$ exposure was found to regulate a group of genes that interfere with the memory and synaptic plasticity molecule cyclic adenosine monophosphate (cAMP) response element-binding protein (CREB) in nerve growth factorprimed PC12 cells [3]. CREB is phosphorylated during 
memory processes by activation of a series of second messenger systems [4-7]. Its phosphorylation leads to binding to CREB binding protein (CBP), a histone acetyltransferase (HAT) that (similar to other HATs) functions as a coactivator that catalyzes histone acetylation, causing an increase in the transcription of memory-associated genes [8-13]. This effect on acetylation is counteracted by histone deacetylases (HDACs) which were found to remove an acetyl group from histones, thus reducing gene expression levels. It is therefore likely that derangement of the enzymatic pathways leading to CREB phosphorylation, as well as the transcription machinery interacting with CREB during memory formation, play a key role in synaptic dysfunction and memory loss in AD. Most importantly, targeting the enzymatic pathways and the transcription machinery leading to memory formation may be a useful strategy for treating AD. Here we will summarize the literature supporting the idea of targeting 4 enzymatic pathways leading to CREB phosphorylation, including the cAMP/protein kinase A (PKA)/CREB cascade, the serine/threonine kinases extracellular regulated kinase (ERK) 1 and ERK 2 (ERK1/2), the nitric oxide (NO) cascade, and the calcium-activated neutral cysteine proteases (calpains), as well as HATs and HDACs for a therapy against AD.

\section{cAMP/PKA/CREB Cascade}

PKA is one of the canonical kinases involved in synaptic plasticity. Discovered over 40 years ago [14], PKA consists of 2 catalytic components and 2 regulatory components. Various extracellular signals (e.g., synaptic stimulation) induce adenylyl cyclase to produce cAMP, which then binds to the regulatory elements of PKA (PKA-R) resulting in dissociation of PKA-R from the PKA catalytic components. This liberates the PKA catalytic components, which can then phosphorylate (and thus activate) CREB (see [4] for a recent review) (Fig. 1). There is extensive literature examining PKA dysfunction in animal models of $\mathrm{AD}$, which may be induced through $\mathrm{A} \beta-$ mediated oxidative stress [15], as well as through $A \beta$ independent mechanisms, such as direct inhibition of the PKA pathway by $\beta$-secretase (BACE)1 [16]. Moreover, the antiamnestic effects of both caffeine and environmental enrichment in animal models of AD have been linked to promotion of PKA activity $[17,18]$. As an aside, our group has shown that at low physiologic (picomolar) levels, $\mathrm{A} \beta 42$ promotes memory formation [19] (with its depletion reducing learning and memory [20]), and this effect has also been linked to enhancement of the PKA pathway [21]. Finally, our group has shown that pathologic (nanomolar) concentrations of $\mathrm{A} \beta 42$ cause a rapid and sustained decrease in PKA activity and inhibition of CREB phosphorylation in hippocampal neuronal cultures in response to glutamate stimulation [3].

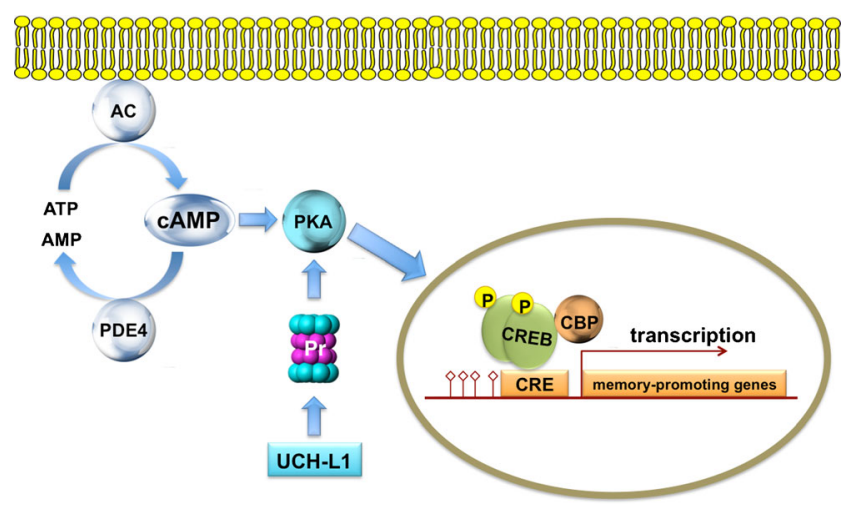

Fig. 1 A schematic representation of the cyclic adenosine monophosphate (cAMP) signaling cascade. Activation of adenylyl cyclase (AC) leads to the formation of cAMP from adenosine triphosphate (ATP). Phosphodiesterase 4 (PDE4) degrades cAMP in AMP. cAMP activates protein kinase A (PKA), which phosphorylates cAMPresponsive element-binding protein (CREB). CREB phosphorylation activates the transcription machinery. DNA (red line) is part of the transcription machinery. Of note, Uch-L1 activates proteasomal $(\mathrm{Pr})$ degradation of the PKA regulatory subunit, which also promotes CREB phosphorylation through PKA activation. $\mathrm{CRE}=$ cAMP response element; $\mathrm{CBP}=\mathrm{CREB}$ binding protein; $\mathrm{p}=$ phospho group

Given the importance of cAMP [as well as cyclic guanosine monophosphate (cGMP) - see below] in the central nervous system, many neuroscientists have become interested in the regulation of cAMP and cGMP. Both cyclic nucleotides are primarily regulated by a family of enzymes called phosphodiesterases (PDEs). PDEs hydrolyze cAMP and cGMP into 5'AMP and 5' GMP, respectively [22]. In particular, PDE4 has been shown to be a major regulator of cAMP [23, 24]. Thus, PDE4 inhibition has been proposed as a therapeutic strategy that can lead to cAMP elevation and increased CREB phosphorylation. Rolipram is a prominent PDE4 inhibitor that has been tested in multiple animal models of $\mathrm{AD}$ for this reason [25]. For example, the APP/PS1 mouse model of $\mathrm{AD}$ displays impaired synaptic plasticity and memory as early as 3-4 months of age [26], and our group has found that rolipram rescues LTP, contextual fear conditioning, and spatial working memory in these mice [27]. In this same study, it was shown that improvements in synaptic plasticity and memory persisted for several months after the last dose of rolipram, and this was accompanied by a reversal of the observed decrease in CREB phosphorylation in these mice. A separate study by Cheng et al. [28] found that rolipram treatment reversed the memory deficits seen in rats treated with $A \beta 1$ 40. In this study, rolipram also reversed the memory deficits caused by $A \beta 25-35$ (the core fragment of $A \beta 1-40$ ). Rescue of memory impairment in this animal model was also accompanied by an elevation of phosphorylated CREB. Finally, a third study has examined the effects of PDE4 micro-RNA knockdown in an additional rodent model of AD [29]. In this study, PDE4 knockdown in mice reversed memory deficits caused by hippocampal injection of $A \beta 1-42$. Consistent with the 
previous 2 studies, this improvement in memory was accompanied by an increase in phosphorylated CREB. The consistency of the results across all of these studies supports the use PDE4 inhibition as a treatment of memory dysfunction in AD. As an aside, some have questioned the use of rolipram as an antiamnestic in humans owing to its side effect of severe emesis [30]. In response, newer PDE4 inhibitors have been developed that improve memory without the side effects of rolipram [31], and which are still effective months after chronic treatment [32], similarly to rolipram.

All these data lead to the obvious question: Is there impaired PKA activity in the brains of patients with AD? Although this question has not been answered directly, there is circumstantial evidence to support this idea. The brains of patients with $\mathrm{AD}$ show an accumulation of ubiquitinated proteins [33], suggesting inhibition of the protein degradation machinery. Could there be impaired degradation of PKA-R in $\mathrm{AD}$ ? If this were to occur, it would result in increased binding of PKA-R to the PKA catalytic domain, which would lead to increased inhibition of PKA. Uch-L1, a neuron- and testisspecific enzyme, is associated with protein ubiquitination and long-term facilitation in Aplysia [34, 35] (Fig. 1). In addition, Uch-L1 is downregulated in AD brains [36]. There may also be a loss of soluble Uch-L1 in AD brains; NFTs stain for UchL1, and levels of soluble Uch-L1 are inversely proportional to tangle burden [36]. This circumstantial evidence has generated interest in studying the mechanism of how decreased UchL1 levels may contribute to synaptic dysfunction in AD. The hypothesis is that Uch-L1 normally participates in the degradation of the PKA-R protein, which then allows the PKA catalytic domain to phosphorylate (i.e., activate) CREB. Therefore, when Uch-L1 activity is impaired, PKA-R is not degraded as quickly, the PKA catalytic domain is sequestered, and CREB phosphorylation is impaired.

Our group has investigated the above hypothesis [37], and we have shown that 1) Uch-L1 protein levels are reduced in the hippocampus of APP/PS1 mice; 2) inhibiting Uch-L1 activity leads to an impairment of hippocampal LTP; and 3) supplementing Uch-L1 protein restores LTP and associative memory in $A P P / P S 1$ mice and blocks the $\mathrm{A} \beta$-induced reduction in PKA activity [37]. Additional work has also shown that Uch-L1 treatment can restore spine density in mouse models of $\mathrm{AD}$, and this effect is seen even in elderly mice [38]. Thus, upregulating Uch-L1 activity may be a therapeutic strategy for rescuing synaptic function in $\mathrm{AD}$ [39]. As an aside, Uch-L1 has also been shown to be associated with Parkinson's disease. Liu et al. [40] have shown that farnesylation promotes the association of Uch-L1 with cellular membranes, and that this correlates with $\alpha$-synuclein pathology. The mechanism for this association is unclear, but may relate to loss of functional (soluble) Uch-L1 from the cytoplasm. In any case, farnesyltransferase inhibition reduces $\alpha$-synuclein levels and improves cell survival in cultures, suggesting that Uch-L1 may also be a therapeutic target for Parkinson's disease.

\section{The ERK1/2 Mitogen-Activated Protein Kinase Pathway}

Signaling cascades involving ERK1/2 constitute another pathway that leads to CREB phosphorylation [41]. ERK1/2 are components of 1 of 4 related, but distinct, mitogen-activated protein kinase (MAPK) pathways that also include the c-Jun $\mathrm{N}$-terminal kinase/stress-activated protein kinase [42, 43], the p38MAPK [44], and ERK5/big MAP kinase 1 [45] pathways. The canonical ERK signaling pathway consists of a molecular cascade wherein receptor tyrosine kinase activation leads to activation of the guanosine-5'-triphosphatase-activating protein, son of sevenless (SOS), via the adaptor proteins Shc and Grb2 (Fig. 2). SOS then activates the small guanosine triphosphate-binding protein, Ras, that initiates a 3-member kinase cascade that is the hallmark of MAPK pathways. In the case of ERK, this cascade consists of Raf, mitogen/ extracellular signal-regulated kinase and ERK1/2 [46]. CREB phosphorylation occurs when ERK translocates to the nucleus to phosphorylate CREB kinases. In the case of neurotrophininduced CREB phosphorylation, Msk1 appears to be the critical kinase mediating CREB phosphorylation [47].

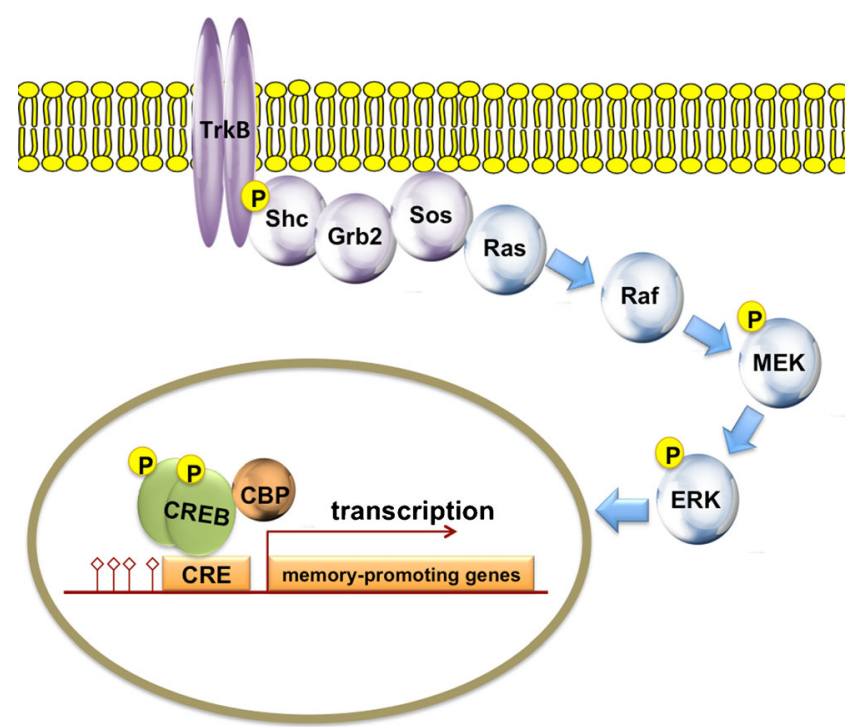

Fig. 2 A schematic representation of the canonical mitogen-activated protein kinase (MAPK) signaling cascade. Receptor tyrosine kinase activation leads to activation of the guanosine triphosphatase-activating protein, son of sevenless (Sos), via the adaptor proteins Shc and Grb2, and the small guanosine triphosphate-binding protein, Ras. Ras initiates a 3-member kinase cascade that, in the case of extracellular regulated kinase (ERK), consists of Raf, mitogen/extracellular signal-regulated kinase (MEK) and ERK1/2. CREB phosphorylation occurs when ERK translocates to the nucleus to phosphorylate cyclic adenosine monophosphate (cAMP)-responsive element-binding protein (CREB) kinases. DNA indicated by red line. $\mathrm{CRE}=\mathrm{cAMP}$ response element; $\mathrm{CBP}=\mathrm{CREB}$ binding protein; $\mathrm{p}=$ phospho group 
Support for the notion that ERK-induced CREB phosphorylation may be beneficial for AD-related impairments comes, in part, from studies of brain-derived neurotrophic factor (BDNF) signaling. BDNF induces CREB phosphorylation by binding to its cell surface receptor, TrkB, and activating the ERK signaling cascade. BDNF has been found to enhance synaptic plasticity and promote cell survival in model systems $[48,49]$, both of which are potentially beneficial for AD. Conversely, reduced levels of BDNF in patients with $\mathrm{AD}$ or mild cognitive impairment may contribute to cognitive impairments and disease progression in these individuals [50-53]. Application of sublethal concentrations of $A \beta$ to neurons in culture has also been reported to interfere with BDNF-induced activation of ERK and CREB phosphorylation [54].

Despite data suggesting a beneficial role for BDNFinduced ERK signaling, evidence suggests that ERK signaling plays a more complex role in AD. ERK can be activated by multiple mechanisms and, in turn, can act on multiple targets. In some cases data suggest that the effect of ERK signaling on $\mathrm{AD}$ is likely to be beneficial, and in others that it is likely to be detrimental. Elevated levels of ERK have been reported in the cerebrospinal fluid of patients with AD [55], and increased levels of activated ERK have been found in postmortem $\mathrm{AD}$ brains [55-57]. A similar increase in activated ERK has also been found in the brains of mice that overexpress a mutant form of APP [58]. However, given that ERK is required for normal learning and memory and normal synaptic plasticity $[59,60]$, the extent to which these increases represent contributory or compensatory mechanisms for AD-related impairments remains unclear.

$A \beta$-induced receptor activation is thought to be one of the mechanisms leading to increased ERK activation in $\mathrm{AD}$ brains. The ERK pathway is activated by a number of receptors that bind $\mathrm{A} \beta$, including the ionotropic and metabotropic glutamate receptors $N$-methyl-D-aspartate and mGluR5 [61-65], the receptor for advanced glycation end products $[66,67]$, the $\mathrm{p} 75$ neurotrophin receptor, integrins, and a number of microglial receptors (reviewed in [68]). $A \beta$ also interacts with alpha7 nicotinic receptors, which are required for A $\beta$-induced ERK and CREB phosphorylation [58]. Finally, APP itself may activate the ERK pathway via interactions between its cytoplasmic domain and the adaptor proteins Grb2 and ShcA [69]. To the extent that ERK signaling mediates any of the toxic actions of $A \beta$, this pathway may also contribute to AD. Data consistent with hypothesis come from studies using a synthetic p75 neurotrophin receptor ligand, LM11A-31, which was found to inhibit A $\beta$-induced synaptic dysfunction and memory loss [70].

Excitotoxicity and dysregulated calcium homeostasis are thought to occur in neurons affected by $\mathrm{AD}$, and the resulting increases in intracellular calcium can also activate the ERK pathway via a number of molecular mechanisms $[71,72]$. In addition oxidative stress is thought to play a significant role in $\mathrm{AD}$ pathogenesis and can similarly lead to ERK activation via multiple pathways. Given that ERK activation of CREB induces the expression of a number of antioxidant genes, activation of this pathway may represent an adaptive mechanism to reduce oxidative damage (reviewed in [73]). This contention is supported by the observation that molecularly interfering with CREB increases seizure-induced cell death and production of reactive oxygen species, and blocked the neuroprotective effect of BDNF [74].

In addition to CREB, the ERK pathway regulates 2 proteins that are critically involved in AD: the microtubuleassociated protein, tau [75-81], and APP. In the case of tau, hyperphosphorylation is thought to play a key role in $\mathrm{AD}$ pathogenesis [82], and pharmacological inhibition of ERK1 or molecular inhibition of its upstream activator, Ras, has been found to prevent $A \beta$-induced increases in tau phosphorylation $[83,84]$. In contrast, ERK pathway regulation of APP processing may protect against AD. ERK activation increases soluble APP $\alpha$ production, a downstream product of APP processing, and reduces production of the toxic $A \beta$ peptide $[85,86]$. ERK inhibition also blocks the increase in $\mathrm{A} \beta$ production caused by exposure to high concentrations of $\mathrm{N}$ methyl-D-aspartate in mice. These actions are owing, at least in part, to ERK-dependent regulation of the activity and expression of $\alpha$ - and $\gamma$-secretases, the 2 enzymes responsible for APP processing [87-91].

Clearly, the ERK pathway and ERK-mediated CREB phosphorylation play a critical role in AD. While significant progress has been made in unraveling its complex molecular interactions, we still lack a complete understanding of all the ways in which this pathway affects the development and progression of the disease. This understanding will be critical for the future development of $\mathrm{AD}$ therapeutic strategies that target this pathway

\section{The NO Cascade}

$\mathrm{NO}$ is a gaseous molecule released from the conversion of the amino acid L-arginine to L-citrulline by the enzyme NO synthase (NOS). In particular, the neural NO synthase, activated in response to $\mathrm{Ca}^{2+} /$ calmodulin, is widely expressed in the brain, especially in the cortex and hippocampus [92], where it has been implicated in pre- and postsynaptic mechanisms underlying synaptic plasticity (for a review see [93]). $\mathrm{NO}$ acts on soluble receptor guanylate cyclase (sGC) stimulating the production of the second messenger cGMP, which, in turn, is able to activate protein kinase $\mathrm{G}$ (PKG), the activity of which maintains CREB phosphorylation at Ser133 [94, 95] (Fig. 3). NO also mediates CREB-DNA binding via a Ser133independent mechanism by the S-nitrosylation of nuclear proteins associated with CREB target genes [96]. Various 


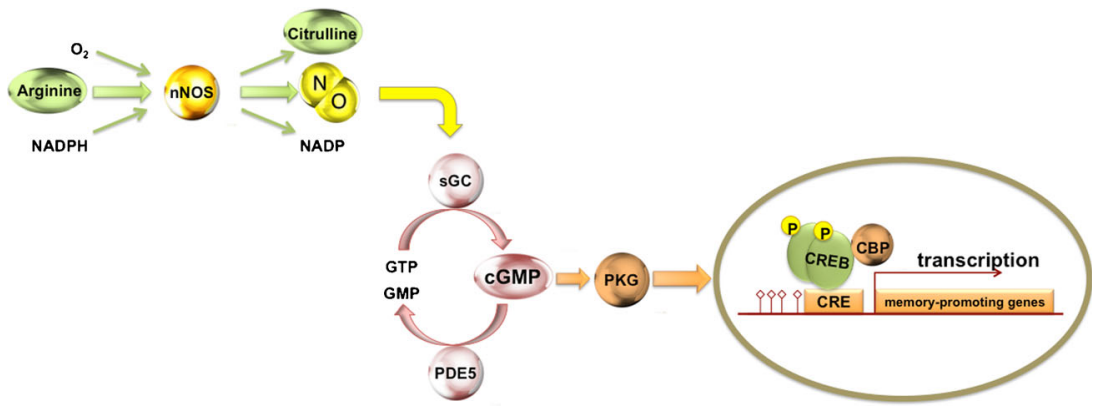

Fig. 3 A schematic representation of the nitric oxide (NO) signaling cascade. NO is formed from the conversion of aminoacid arginine to citrulline by the enzyme neural NO synthase (nNOS). NO activates soluble guanylate cyclase (sGC), which stimulates cyclic guanosine monophosphate (cGMP) production from guanosine triphosphate (GTP). cGMP is degraded in GMP by the enzyme phosphodiesterase 5 (PDE5). The increase of cGMP levels activates protein kinase G (PKG),

studies have suggested that NO/cGMP/PKG and cAMP/PKA cooperate to ensure different phases of LTP and to underpin memory acquisition and consolidation via CREB phosphorylation [94, 97-100]. CREB phosphorylation is now recognized as a crucial event that regulates transcription during synaptic plasticity [101-103], leading to protein synthesis and the generation of new dendritic spines to ensure longterm morphological changes associated with late LTP [104].

The NO/cGMP/PKG/CREB system is disrupted during $A \beta$-induced suppression of synaptic plasticity. This occurs through $\mathrm{A} \beta$-mediated inhibition of NO-induced CREB phosphorylation [105-111], and toxicity may be exacerbated because the NO/cGMP signaling pathway exerts a protective role against $\mathrm{A} \beta$-mediated neurotoxicity [112-114]. We have previously demonstrated that the use of NO donors or cGMP agonists was able to rescue the $\mathrm{A} \beta$-induced impairment of LTP and CREB phosphorylation, whereas sGC or PKG inhibition suppresses this neuroprotective effect [110]. Moreover, sGC activity and cGMP production are blocked by $A \beta$ in brain astroglial cells and tetanized hippocampal slices [109, 110], as well as in temporal cortex of patients with $\mathrm{AD}$ [115].

As PKG phosphorylates (and activates) CREB [94], and the therapeutic effect of cGMP analogs in the setting of elevated $A \beta$ requires PKG function [110], the beneficial effects of cGMP analogs on synaptic plasticity and memory in the setting of elevated A $\beta$ might involve CREB. Several lines of evidence are consistent with this hypothesis: 1) the inhibition of 1 of the components of the NO/cGMP/PKG pathway suppresses CREB phosphorylation [94, 116, 117]; 2) the increase of phospho-CREB during synaptic plasticity is blocked by $A \beta$ in cultured cortical neurons [118], in cultured hippocampal neurons [3], and in hippocampal tetanized slices treated with $A \beta[110]$; and 3) stimulation of the $\mathrm{NO} / \mathrm{sGC} /$ cGMP pathway restores levels of phospho-CREB $[112,113]$. Because of these findings, and considering that the NO cascade is downregulated during aging and in neurodegenerative disorders [112, 113, 119-122], an increasing number of which induces cyclic adenosine monophosphate (cAMP)-responsive element-binding protein (CREB) phosphorylation. DNA indicated by red line. NADP = nicotinamide adenine dinucleotide phosphate; NADPH $=$ reduced form of nicotinamide adenine dinucleotide phosphate (NADP); $\mathrm{CRE}=$ cAMP response element; $\mathrm{CBP}=\mathrm{CREB}$ binding protein; $\mathrm{p}=$ phospho group

studies have focused on therapeutic strategies aimed to regulate this signaling pathway.

Other than classical nitrates or hybrid nitrates, NO donor nonsteroidal anti-inflammatory drugs [123-127], an additional therapeutic approach is to block the degradation of cGMP by using PDE5 inhibitors (PDE5-Is). Over the past few years, our group and others have demonstrated that treatment with PDE5-Is rescues synaptic and memory deficits in the APP/ PS1 mouse model of AD, restoring phospho-CREB levels and decreasing $A \beta$ load $[112,128]$. The PDE5-I sildenafil also exerts the same beneficial effect in a physiological mouse model of aging [113], where it also inhibits apoptosis and increases antiapoptotic molecules Bcl2 and BDNF [129].

The use of PDE5-Is to rescue cognitive function in AD is intriguing, especially given our understanding of the relatively benign side effect profile from long-term use of PDE5-Is to treat male erectile dysfunction. Indeed, similarly to PDE4 inhibition [3], our data suggest that a temporary PDE5-Iinduced upregulation of CREB phosphorylation produces a prolonged beneficial effect that extends beyond the duration of the drug administration. Thus, acting on the NO/cGMP/ PKG/CREB pathway may not only counteract the effects of high levels of $A \beta$, but it could also delay the progression of the disease and prevent or reduce cognitive impairment.

\section{Calpains}

Calpains are a family of at least 15 proteases diffused throughout the body with different specificities [130, 131]. Protein cleavage is an activity typically directed at the catabolism of peptides and protein. However, limited nondigestive proteolysis is also a particular form of post-translational modification changing both the activity and possibly the localization of cell proteins [132]. Calpains are localized in the central nervous system with 2 isoforms (calpain I and II) that are under intense functional characterization [133]. Typically, calcium 
concentration-dependent driven autoproteolysis activates calpains [134], and this phenomenon is dramatically increased in neurodegenerative disease $[135,136]$. Characteristically, calpains clip a small portion of a protein (proactivation cleavage) determining the functional activation of the cleaved protein. A straightforward example of this activity occurs with CaMKII $\alpha$, protein kinase $\mathrm{C}$, and $\mathrm{PP} 3 \alpha /$ calcineurin, all proteins involved in synaptic plasticity and memory mechanisms [137-140], which are activated by calpains by cleavage of their respective inhibitory domain [141-143] (Fig. 4). Calpains hit many targets, including proteins and enzymes involved in mechanisms of synaptic plasticity, learning and memory, transcription factors such as CREB, and translational factors like cytoplasmic polyadenylation element-binding protein 3, a sequence-specific RNA-binding protein that represses translation of its target mRNAs in neurons. Through the regulation of CREB and cytoplasmic polyadenylation element-binding protein $3[144,145]$, calpains indirectly modulate gene transcription or transduction. CREB is composed of a C-terminal promoter-binding domain and an N-terminal transcription regulation domain in which PKA can phosphorylate the amino acid serine in position 133, a step required for the regulation of gene expression along with the dimerization and the inclusion in a transcription complex that includes CBP [146]. Calpain-cleaved CREB preserves serine 133 phosphorylation and recognizes cAMP response element sequences on DNA while losing its major influence in activating the transcription process [144, 145]. However, when calpains are overactivated in response to overshoots of calcium influx, such as in neurodegenerative disease like $\mathrm{AD}$ or ischemic

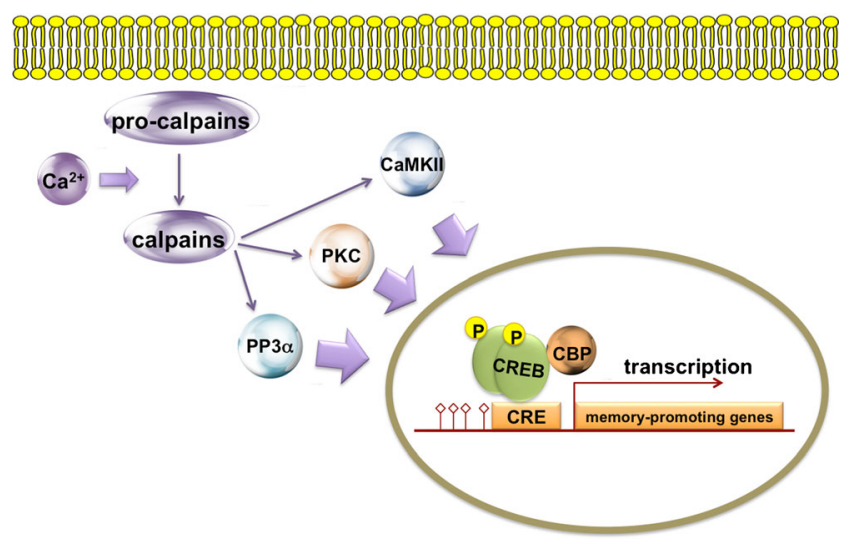

Fig. 4 A schematic representation of calpain activation with enzymes affected by it. Calcium influx induces the cleavage of immature calpains (pro-calpains) to form functional calpains. Calpains activate several proteins involved in plasticity, learning, and memory [protein kinase $\mathrm{C}$ (PKC), calcium-calmodulin kinases II isoform (CaMKII), protein phosphatase $3 \alpha$ /calcineurin (PP3 $\alpha$ )] by limited proteolysis. The activation of these enzymes and their respective biochemical pathways modulates gene transcription. DNA indicated by red line. $\mathrm{CREB}=$ cyclic adenosine monophosphate (cAMP)-responsive element-binding protein; $\mathrm{CRE}=$ cAMP response element; $\mathrm{CBP}=\mathrm{CREB}$ binding protein; $\mathrm{p}=$ phospho group insults [136, 147-153], phosphorylated CREB levels decrease and the phenomenon is accompanied by a decline of both synaptic plasticity and memory [154].

The mechanisms behind the modulatory activity of calpains on plasticity and memory are not well characterized yet and several hypotheses have been proposed over time to rationalize the proteolysis of key targets such as synaptic receptors or kinase activity (see [133] for a recent review). Di Rosa et al. [155] have shown that the cystein protease inhibitor leupeptine decreases the frequency of spontaneous release of neurotransmitter, suggesting a role of calpains in neurotransmitter release. Moreover, calpastatin, the endogenous inhibitor of the calpain system, unravels a function of calpains in learning and memory as rats deficient in calpastatin show enhanced learning and memory [156]. An additional activity is the tight regulation of PKA and, again, CREB activity. Indeed, the decline of PKA levels by calpain activation or overactivation generates, in turn, a correspondent increase in CREB truncation, and decrease in CREB phosphorylation and activation [145, 157], leading to decreased plasticity and poor cognitive performance.

The mechanisms underlying synaptic plasticity are severely impaired in $\mathrm{AD}$ from the early stages of the disease $[1,158$, 159]. One of the culprits of $A D$ is the overactivation of calpains because of calcium homeostasis changes (see [160] for a critical review). Enhanced calpain activation produces augmented APP processing via BACE activation and augmented $A \beta$ deposit [161], increases tau-mediated neuropathology [162], and disrupts the functionality of kinases such as CDK5 by pushing the cleavage of the CDK5 activator p35 [163], but also induces microgliosis, somatodendritic dystrophy, and increased mortality while the endogenous calpain inhibitor calpastatin is knocked down in animal models of AD [164]. This evidence supports the possible use of calpain inhibitors as a therapeutic treatment in AD [153-155]. The field of medicinal chemistry is currently engaged in producing a variety of molecules as possible calpain inhibitor candidates $[165,166]$. Most of them are chemically-related to a natural compound called E-64 that irreversibly but not selectively inhibits calpains [167-169]. E64 exhibits excellent activity in transgenic models of $\mathrm{AD}$ in vitro and in vivo $[154,170]$, rescuing the $\mathrm{AD}$ phenotype in terms of synaptic plasticity and memory. However, the nonselective nature of E-64 seems unfavorable for clinical use, so an interesting development for this class of compounds against $\mathrm{AD}$ is the development of a novel calpain I-selective peptidomimetic, based on E-64 as a lead compound. Schiefer et al. [171] designed a new series of derivatives with favorable pharmacodynamic characteristics that maintain drug potency while increasing calpain I selectivity and druggability [171]. BDA-410, an orally active synthetic Leu-Leu peptidomimetic rescues synaptic plasticity defects and memory impairment in an APP/PS1 AD mouse model but does not alter $\mathrm{A} \beta$ productions and increases CREB phosphorylation [154]. This fact 
confirms the efficiency of the epoxide derivatives toward AD. Other inhibitors such as AK 295 or MDL 28170 have never been thoroughly characterized as AD therapeutics, although MDL 28170 is known to inhibit $\gamma$-secretase, responsible for the cleavage of APP to produce A $\beta[172,173]$. Another orally active and very promising compound is A-705253, a benzoylalanine-derived ketoamide that is under intense scrutiny and characterization. A-705253 proved to be active in the prevention of both tau phosphorylation and cleavage [174, $175]$, and it is active in the 3xTgAD mouse model rescuing memory defects, reducing levels of BACE enzyme and A $\beta$ deposits, decreasing overall neuroinflammation $[174,176]$. Taken together, these data suggest that calpain inhibition might be an efficient and reliable target for AD therapy.

\section{HDACs and HATs}

During memory formation CREB binds to CBP, an enzyme with HAT activity, representing one of the epigenetic processes leading to chromatin remodeling and DNA transcription (Fig. 5). CBP belongs to 1 of the 5 major HAT groups: CBP/ p300; Gcn5-related N-acetyltransferases (including Gcn5 and p300/CBP-associated factor); MYST (MOZ, Ybf2, Sas2, and Tip60); nuclear receptor-associated HATs; and transcription factor-related HATs [177]. On the other side, HDACs function to remove acetyl groups from histone lysines, repressing gene transcription. The HDAC family comprises 18 members, grouped into 4 classes: HDAC I (HDACs $1-3$ and HDAC 8 ); HDAC II, which is divided into IIA (HDAC4, HDAC5, HDAC7, and HDAC9) and IIB (HDAC6 and HDAC10); HDAC III (Sirt 1-7); and HDAC IV (HDAC11) [177, 178]. In the last decade the correlation between learning and memory and histone acetylation has been deeply explored [8-12]. Studies have shown that acetylation levels of histone 3 and histone 4 are increased during spatial and associative learning

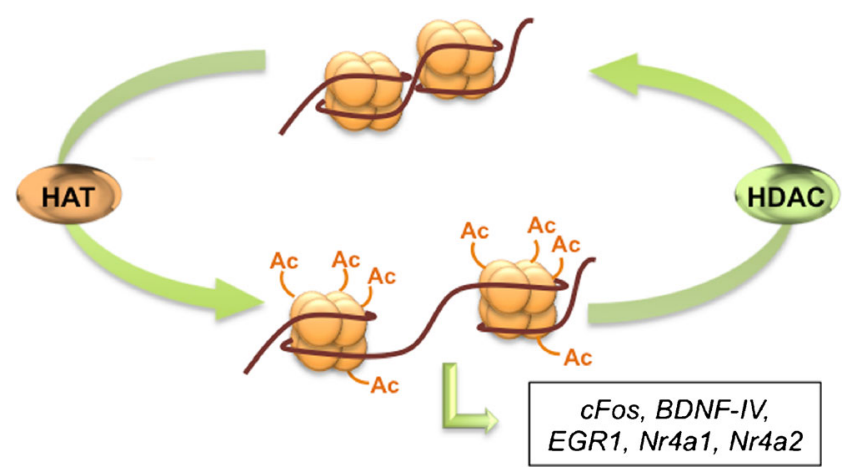

Fig. 5 A schematic representation of the histone acetyltransferases (HAT)/histone deacetylases (HDAC) system. HATs add acetyl groups (Ac) to histones, reducing the binding of DNA to the histones. DNA becomes accessible for the transcription of memory-related genes. Conversely, HDACs remove acetyl groups from histone proteins, preventing DNA transcription in the hippocampus and cortex $[8,179,180]$. The increase of histone acetylation levels leads to transcription of memorypromoting genes, such as $c F o s, B D N F-I V, E G R 1$, and Nr4al and Nr4a2 [181-184] (Fig. 5). Regulation of gene transcription via modification of chromatin structure has been of particular interest for the treatment of various diseases. Recently, the alteration of HDAC and HAT activity by using small molecules, that is HDAC inhibitors and HAT activators, has been considered as a possible therapeutic avenue for the treatment of $\mathrm{AD}[185,186]$.

Alteration of histone acetylation levels are related to the processes of memory consolidation [8-13]. A number of studies have focused on the role of HDAC inhibitors (HDACi) in enhancing LTP and long-term memory (LTM) in rodents and mutant mouse models. Synaptic plasticity was increased in hippocampus slices, from APP/PS1 mice, perfused with trichostatin A (TSA), a well-known class I/II HDACi [186]. Also, in a contextual fear conditioning assessment, TSA was shown to rescue spatial memory deficits in APP/PS1 mice [186]. Both TSA and sodium butyrate (class I/II HDACi) were able to ameliorate LTP in hippocampus slices from Sprague-Dawley rats [8]. In addition, sodium butyrate enhanced freezing in Sprague-Dawley rats and in CK-p25 mutant mice [8, 179], and improved the LTM of $c b p$ mutant mice in a novel object recognition task [187]. Another study showed that in a visualpaired comparison task CBP mutant mice (in which HAT activity is eliminated) displayed impaired LTM, which was rescued after treatment with TSA [11]. Mutant mice that express a truncated form of CBP $\left(\mathrm{cbp}^{+/}\right)$showed impaired LTM in novel object recognition task and reduced synaptic plasticity than wild-type mice. Treatment with suberoylanilide hydroxamic acid (HDAC I/HDAC II inhibitor) rescued memory deficits and increased LTP in slices of hippocampus [9]. Consistent with previous results, treatment with the HDACi sodium 4-phenylbutyrate restored synaptic plasticity and memory impairment in $\mathrm{Tg} 2576$ mice [188]. To define the molecular pathways underlying histone acetylation modifications during memory consolidation, Vecsey et al. [184] demonstrated that the interaction between CREB and the transcriptional coactivator $\mathrm{CBP}$ was required to enhance the LTP after treatment with HDACi. They found that TSA was not able to enhance LTP or freezing levels in CREB $\alpha \Delta$ and $c b p^{\mathrm{KIX} /}$ KIX mutant mice in which the formation of the CREB-CBP complex was disrupted. Moreover, TSA enhanced the expression of $\mathrm{Nr} 4 \mathrm{al}$ and $\mathrm{Nr} 4 \mathrm{a} 2$ after fear conditioning in wild-type mice but not in CREB $\alpha \Delta$ mutant mice, suggesting that $N r 4 a 1$ and $N r 4 a 2$ expression was CREB-CBP dependent after contextual fear conditioning. To investigate whether the CBP homolog, the transcriptional coactivator p300, was also involved in LTM formation, Oliveira et al. [189] tested a transgenic mice model, p $300 \Delta 1$, in which the HAT domain of the p300 protein was truncated. These transgenic mice showed impairment in recognition and contextual fear memory, demonstrating that $\mathrm{p} 300$ was required in the gene transcription induced by learning processes. 
It also been reported that loss of $\mathrm{p} 300 / \mathrm{CBP}$-associated factor leads to LTM deficits in 6- and 12-month-old mice [190]. Thus, HAT activity seems to be necessary for establishing LTM formation and consolidation owing to its involvement in learningdependent chromatin remodeling. Lately, an alternative approach to modulating the acetylation levels of histones has been represented by employing small HAT activator molecules for treating neurodegenerative disorders [177]. A few HAT activators have been discovered and 2 of them used for studying brain functions in vivo [191, 192]. Wei et al. [191] evaluated the effects of a PCAF activator, SPV106, on fear conditioning and extinction. As a result, PCAF activity was found to facilitate the formation of fear extinction memory without affecting fear acquisition. Instead, Chatterjee et al. [192] reported the beneficial implications of TTK21, a p300/CBP activator, on LTM by testing spatial learning and memory in the Morris water maze task. Overall, molecules able to modulate the levels of histone acetylation, such as HDACi and HAT activators, represent a promising approach for treating cognitive aspects of neurodegenerative disorders. Despite the growing interest in investigating how chromatin manipulation lies behind the processes of learning and memory, further effort is still required in terms of drug design, specificity, and brain targeting.

\section{Conclusions}

Over the last 15 years a large amount of work has been performed on CREB and its possible exploitation for a therapy against $\mathrm{AD}$. When our laboratories and others started this research, the use of drugs enhancing CREB activation was envisioned as a strategy that could work at the downstream level of $A \beta$ and was therefore probably devoid of any putative side effect due the physiological function/s of APP and its downstream products, as well as the secretases responsible for APP processing [19, 20, 193-197]. Nevertheless, should drugs acting onto amyloid deposition or even drugs interfering with NFT formation provide a safe and effective approach against $\mathrm{AD}$, one can envision a scenario in which agents enhancing CREB activation are given in a combination therapy with anti-A $\beta$ and/or anti-tau therapies.

Given all of the success in rescuing memory through CREB function in $\mathrm{AD}$, an important question should be asked: Is there any downside to chronically increasing CREB phosphorylation? It is also important to remember that CREB is involved in a wide range of physiological processes in a range of tissues [198], and that CREB is also an oncogene [199]. Moreover, one can predict that our knowledge of the regulation of CREB will evolve with time as new studies unravel novel aspects of the complex mechanisms regulating its activation and elucidate its role in learning and memory. These caveats have led some to question whether a CREB-centric approach is a viable therapeutic strategy at all [198]. These are important issues.
However, it is important to realize that we are not advocating for long-term pharmacologic elevation of CREB activity above normal levels, but rather to rescue the impairment in CREB phosphorylation seen in AD. Thus, although the ultimate test will be clinical trial data, there is reason to suspect that a CREBcentric approach will be successful.

Acknowledgments This work was supported by National Institutes of Neurological Disorders and Stroke grant \#NS049442 to Ottavio Arancio; Alzheimer's Association grants \#NIRG-13-283742 to Andrew F. Teich; and \#IIRG-09-134220 to Daniela Puzzo.

Required Author Forms Disclosure forms provided by the authors are available with the online version of this article.

\section{References}

1. Masliah E. Mechanisms of synaptic dysfunction in Alzheimer's disease. Histol Histopathol 1995;10:509-519.

2. Selkoe DJ. Alzheimer's disease is a synaptic failure. Science 2002;298:789-791.

3. Vitolo OV, Sant'Angelo A, Costanzo V et al. Amyloid beta-peptide inhibition of the PKA/CREB pathway and long-term potentiation: reversibility by drugs that enhance cAMP signaling. Proc Natl Acad Sci U S A 2002;99:13217-13221.

4. Kandel ER. The molecular biology of memory: cAMP, PKA, CRE, CREB-1, CREB-2, and CPEB. Mol Brain 2012;5:14.

5. Silva AJ, Kogan JH, Frankland PW, Kida S. CREB and memory. Annu Rev Neurosci 1998;21:127-148.

6. Barco A, Alarcon JM, Kandel ER. Expression of constitutively active CREB protein facilitates the late phase of long-term potentiation by enhancing synaptic capture. Cell 2002;108:689-703.

7. Benito E, Barco A. CREB's control of intrinsic and synaptic plasticity: implications for CREB-dependent memory models. Trends Neurosci 2010;33:230-240.

8. Levenson JM, O' Riordan KJ, Brown KD, Trinh MA, Molfese DL, Sweatt JD. Regulation of histone acetylation during memory formation in the hippocampus. J Biol Chem 2004;279:40545-40559.

9. Alarcón JM, Malleret G, Touzani K, et al. Chromatin acetylation, memory, and LTP are impaired in CBP+/- mice: a model for the cognitive deficit in Rubinstein-Taybi syndrome and its amelioration. Neuron 2004;42:947-959.

10. Peixoto L, Abel T. The role of histone acetylation in memory formation and cognitive impairments. Neuropsychopharmacology 2013;38:62-76.

11. Korzus E, Rosenfeld MG, Mayford M. CBP histone acetyltransferase activity is a critical component of memory consolidation. Neuron 2004;42:961-972.

12. Peleg S, Sananbenesi F, Zovoilis A, et al. Altered histone acetylation is associated with age-dependent memory impairment in mice. Science 2010;328:753-756.

13. Kandel ER. The molecular biology of memory storage: a dialog between genes and synapses. Biosci Rep 2001;21:565-611.

14. Corbin JD, Krebs EG. A cyclic AMP-stimulated protein kinase in adipose tissue. Biochem Biophys Res Commun 1969;36: 328-336.

15. Du H, Guo L, Wu X, et al. Cyclophilin D deficiency rescues Abetaimpaired PKA/CREB signaling and alleviates synaptic degeneration. Biochim Biophys Acta 2014;1842:2517-2527.

16. Chen Y, Huang X, Zhang YW et al. Alzheimer's beta-secretase (BACE1) regulates the cAMP/PKA/CREB pathway independently of beta-amyloid. J Neurosci 2012;32:11390-11395. 
17. Zeitlin R, Patel S, Burgess S, Arendash GW, Echeverria V. Caffeine induces beneficial changes in PKA signaling and JNK and ERK activities in the striatum and cortex of Alzheimer's transgenic mice. Brain Res 2011;1417:127-136.

18. Li S, Jin M, Zhang D et al. Environmental novelty activates beta2adrenergic signaling to prevent the impairment of hippocampal LTP by Abeta oligomers. Neuron 2013;77:929-941.

19. Puzzo D, Privitera L, Leznik E et al. Picomolar amyloid-beta positively modulates synaptic plasticity and memory in hippocampus. J Neurosci 2008;28:14537-14545.

20. Puzzo D, Privitera L, Fa M et al. Endogenous amyloid-beta is necessary for hippocampal synaptic plasticity and memory. Ann Neurol 2011;69:819-830.

21. Ricciarelli R, Puzzo D, Bruno O et al. A novel mechanism for cyclic adenosine monophosphate-mediated memory formation: Role of amyloid beta. Ann Neurol 2014;75:602-607.

22. Azevedo MF, Faucz FR, Bimpaki E et al. Clinical and molecular genetics of the phosphodiesterases (PDEs). Endocr Rev 2014;35:195233 .

23. Conti M, Richter W, Mehats C et al. Cyclic AMP-specific PDE4 phosphodiesterases as critical components of cyclic AMP signaling. J Biol Chem 2003;278:5493-5496.

24. Houslay MD, Adams DR. PDE4 cAMP phosphodiesterases: modular enzymes that orchestrate signalling cross-talk, desensitization and compartmentalization. Biochem J 2003;370:1-18.

25. Ke H. Implications of PDE4 structure on inhibitor selectivity across PDE families. Int J Impot Res 2004;16(Suppl. 1):S24-S27.

26. Trinchese F, Liu S, Battaglia F et al. Progressive age-related development of Alzheimer-like pathology in APP/PS1 mice. Ann Neurol 2004;55:801-814

27. Gong B, Vitolo OV, Trinchese $\mathrm{F}$ et al. Persistent improvement in synaptic and cognitive functions in an Alzheimer mouse model after rolipram treatment. J Clin Invest 2004;114:1624-1634.

28. Cheng YF, Wang C, Lin HB et al. Inhibition of phosphodiesterase-4 reverses memory deficits produced by Abeta25-35 or Abeta1-40 peptide in rats. Psychopharmacology (Berl) 2010;212:181-191.

29. Zhang C, Cheng Y, Wang H et al. RNA interference-mediated knockdown of long-form phosphodiesterase-4D (PDE4D) enzyme reverses amyloid-beta42-induced memory deficits in mice. J Alzheimers Dis 2014;38:269-280.

30. Hebenstreit GF, Fellerer K, Fichte K et al. Rolipram in major depressive disorder: results of a double-blind comparative study with imipramine. Pharmacopsychiatry 1989;22:156-160.

31. Bruno O, Fedele E, Prickaerts J et al. GEBR-7b, a novel PDE4D selective inhibitor that improves memory in rodents at non-emetic doses. Br J Pharmacol 2011;164:2054-2063.

32. Sierksma AS, van den Hove DL, Pfau F et al. Improvement of spatial memory function in APPswe/PS1dE9 mice after chronic inhibition of phosphodiesterase type 4D. Neuropharmacology 2014;77:120-130.

33. de Vrij FM, Fischer DF, van Leeuwen FW, Hol EM. Protein quality control in Alzheimer's disease by the ubiquitin proteasome system. Prog Neurobiol 2004;74:249-270.

34. Setsuie R, Wada K. The functions of UCH-L1 and its relation to neurodegenerative diseases. Neurochem Int 2007;51:105-111.

35. Chain DG, Casadio A, Schacher S et al. Mechanisms for generating the autonomous cAMP-dependent protein kinase required for long-term facilitation in Aplysia. Neuron 1999;22: 147-156.

36. Choi J, Levey AI, Weintraub ST et al. Oxidative modifications and down-regulation of ubiquitin carboxyl-terminal hydrolase L1 associated with idiopathic Parkinson's and Alzheimer's diseases. J Biol Chem 2004;279:13256-13264.

37. Gong B, Cao Z, Zheng P et al. Ubiquitin hydrolase uch-L1 rescues beta-amyloid-induced decreases in synaptic function and contextual memory. Cell 2006;126:775-788.
38. Smith DL, Pozueta J, Gong B, Arancio O, Shelanski M. Reversal of long-term dendritic spine alterations in Alzheimer disease models. Proc Natl Acad Sci U S A 2009;106:16877-16882.

39. Gong B, Leznik E. The role of ubiquitin C-terminal hydrolase L1 in neurodegenerative disorders. Drug News Perspect 2007;20:365-370.

40. Liu Z, Meray RK, Grammatopoulos TN et al. Membrane-associated farnesylated UCH-L1 promotes alpha-synuclein neurotoxicity and is a therapeutic target for Parkinson's disease. Proc Natl Acad Sci U S A 2009;106:4635-4640.

41. Sakamoto K, Karelina K, Obrietan K. CREB: a multifaceted regulator of neuronal plasticity and protection. J Neurochem 2011;116:1-9.

42. Coffey ET. Nuclear and cytosolic JNK signalling in neurons. Nat Rev Neurosci 2014;15:285-299.

43. Yin F, Jiang T, Cadenas E. Metabolic triad in brain aging: mitochondria, insulin/IGF-1 signalling and JNK signalling. Biochem Soc Trans 2013;41:101-105.

44. Munoz L, Ammit AJ. Targeting p38 MAPK pathway for the treatment of Alzheimer's disease. Neuropharmacology 2010;58:561568.

45. Obara Y, Nakahata N. The signaling pathway leading to extracellular signal-regulated kinase 5 (ERK5) activation via G-proteins and ERK5dependent neurotrophic effects. Mol Pharmacol 2010;77:10-16.

46. Keshet Y, Seger R. The MAP kinase signaling cascades: a system of hundreds of components regulates a diverse array of physiological functions. Methods Mol Biol 2010;661:3-38.

47. Arthur JS, Fong AL, Dwyer JM et al., Mitogen- and stress-activated protein kinase 1 mediates cAMP response element-binding protein phosphorylation and activation by neurotrophins. J Neurosci 2004;24:4324-4332.

48. Diniz BS, Teixeira AL. Brain-derived neurotrophic factor and Alzheimer's disease: physiopathology and beyond. Neuromolecular Med 2011;13:217-222.

49. Schulte-Herbruggen O, Jockers-Scherubl MC, Hellweg R. Neurotrophins: from pathophysiology to treatment in Alzheimer's disease. Curr Alzheimer Res 2008;5:38-44.

50. Laske C, Stransky E, Leyhe T, et al. Stage-dependent BDNF serum concentrations in Alzheimer's disease. J Neural Transm 2006;113: $1217-1224$.

51. Lee JG, Shin BS, You YS, et al. Decreased serum brain-derived neurotrophic factor levels in elderly korean with dementia. Psychiatry Investig 2009;6:299-305.

52. Zhang J, Sokal I, Peskind ER, et al. CSF multianalyte profile distinguishes Alzheimer and Parkinson diseases. Am J Clin Pathol 2008;129:526-529.

53. Li G, Peskind ER, Millard SP et al. Cerebrospinal fluid concentration of brain-derived neurotrophic factor and cognitive function in non-demented subjects. PLoS One 2009;4:e5424.

54. Tong L, Balazs R, Thornton PL, Cotman CW. Beta-amyloid peptide at sublethal concentrations downregulates brain-derived neurotrophic factor functions in cultured cortical neurons. J Neurosci 2004;24:67996809.

55. Zhu X, Castellani RJ, Takeda A et al. Differential activation of neuronal ERK, JNK/SAPK and p38 in Alzheimer disease: the 'two hit' hypothesis. Mech Ageing Dev 2001;123:39-46.

56. Perry G, Roder H, Nunomura A et al. Activation of neuronal extracellular receptor kinase (ERK) in Alzheimer disease links oxidative stress to abnormal phosphorylation. Neuroreport 1999;10:2411-2415.

57. Ferrer I, Blanco R, Carmona $M$ et al. Phosphorylated map kinase (ERK1, ERK2) expression is associated with early tau deposition in neurones and glial cells, but not with increased nuclear DNA vulnerability and cell death, in Alzheimer disease, Pick's disease, progressive supranuclear palsy and corticobasal degeneration. Brain Pathol 2001;11:144-158.

58. Dineley KT, Westerman M, Bui D, Bell K, Ashe KH, Sweatt JD. Beta-amyloid activates the mitogen-activated protein kinase cascade via hippocampal alpha7 nicotinic acetylcholine receptors: In 
vitro and in vivo mechanisms related to Alzheimer's disease. J Neurosci 2001;21:4125-4133.

59. Sweatt JD. The neuronal MAP kinase cascade: a biochemical signal integration system subserving synaptic plasticity and memory. J Neurochem 2001;76:1-10.

60. Samuels IS, Saitta SC, Landreth GE. MAP'ing CNS development and cognition: an ERKsome process. Neuron 2009;61:160-167.

61. Wang JQ, Fibuch EE, Mao L. Regulation of mitogen-activated protein kinases by glutamate receptors. J Neurochem 2007;100:1-11.

62. Werry TD, Christopoulos A Sexton PA. Mechanisms of ERK1/2 regulation by seven-transmembrane-domain receptors. Curr Pharm Design 2006;12:1683-1702.

63. De Felice FG, Velasco PT, Lambert MP et al. Abeta oligomers induce neuronal oxidative stress through an N-methyl-D-aspartate receptor-dependent mechanism that is blocked by the Alzheimer drug memantine. J Biol Chem 2007;282:11590-11601.

64. Cowburn RF, Wiehager B, Trief E, Li-Li M, Sundstrom E. Effects of beta-amyloid-(25-35) peptides on radioligand binding to excitatory amino acid receptors and voltage-dependent calcium channels: evidence for a selective affinity for the glutamate and glycine recognition sites of the NMDA receptor. Neurochem Res 1997;22:1437-1442.

65. Um JW, Kaufman AC, Kostylev M et al. Metabotropic glutamate receptor 5 is a coreceptor for Alzheimer abeta oligomer bound to cellular prion protein. Neuron 2013;79:887-902.

66. Origlia N, Arancio O, Domenici L, Yan SS. MAPK, beta-amyloid and synaptic dysfunction: the role of RAGE. Expert Rev Neurother 2009;9:1635-1645.

67. Origlia N, Criscuolo C, Arancio O, Yan SS, Domenici L. RAGE inhibition in microglia prevents ischemia-dependent synaptic dysfunction in an amyloid-enriched environment. J Neurosci 2014;34: 8749-8760.

68. Balleza-Tapia H, Pena F. Pharmacology of the intracellular pathways activated by amyloid beta protein. Mini Rev Med Chem 2009;9:724740 .

69. Schettini G, Govoni S, Racchi M, Rodriguez G. Phosphorylation of APP-CTF-AICD domains and interaction with adaptor proteins: signal transduction and/or transcriptional role-relevance for Alzheimer pathology. J Neurochem 2010;115:1299-1308.

70. Knowles JK, Simmons DA, Nguyen TV et al. Small molecule p75NTR ligand prevents cognitive deficits and neurite degeneration in an Alzheimer's mouse model. Neurobiol Aging 2013;34:20522063.

71. Rosen LB, Simmons DA, Nguyen TV et al. Membrane depolarization and calcium influx stimulate MEK and MAP kinase via activation of Ras. Neuron 1994;12:1207-1221.

72. Sindreu CB, Scheiner ZS, Storm DR. Ca2+ -stimulated adenylyl cyclases regulate ERK-dependent activation of MSK1 during fear conditioning. Neuron 2007;53:79-89.

73. Chu CT, Levinthal DJ, Kulich SM, Chalovich EM, DeFranco DB. Oxidative neuronal injury: The dark side of ERK1/2. Eur J Biochem 2004;271:2060-2066.

74. Lee B, Cao R, Choi YS et al. The CREB/CRE transcriptional pathway: protection against oxidative stress-mediated neuronal cell death. J Neurochem 2009;108:1251-1265.

75. Drewes G, Lichtenberg-Kraag B, Doring F et al. Mitogen activated protein (MAP) kinase transforms tau protein into an Alzheimer-like state. EMBO J 1992;11:2131-2138.

76. Reynolds CH, Betts JC, Blackstock WP, Nebreda AR, Anderton BH. Phosphorylation sites on tau identified by nanoelectrospray mass spectrometry: differences in vitro between the mitogen-activated protein kinases ERK2, c-Jun N-terminal kinase and P38, and glycogen synthase kinase-3beta. J Neurochem 2000;74:1587-1595.

77. Lu Q, Wood JG. Functional studies of Alzheimer's disease tau protein. J Neurosci 1993;13:508-515.

78. Ekinci FJ, Shea TB. Hyperactivation of mitogen-activated protein kinase increases phospho-tau immunoreactivity within human neuroblastoma: additive and synergistic influence of alteration of additional kinase activities. Cell Mol Neurobiol 1999;19:249-260.

79. Guise S, Braguer D, Carles G, Delacourte A, Briand C. Hyperphosphorylation of tau is mediated by ERK activation during anticancer drug-induced apoptosis in neuroblastoma cells. J Neurosci Res 2001;63:257-267.

80. Garver TD, Oyler GA, Harris KA et al. Tau phosphorylation in brain slices: pharmacological evidence for convergent effects of protein phosphatases on tau and mitogen-activated protein kinase. Mol Pharmacol 1995;47:745-756.

81. Holzer M, Rodel L, Seeger G et al. Activation of mitogenactivated protein kinase cascade and phosphorylation of cytoskeletal proteins after neurone-specific activation of p21ras. II. Cytoskeletal proteins and dendritic morphology. Neuroscience 2001;105:1041-1054.

82. Spillantini MG, Goedert M. Tau pathology and neurodegeneration. Lancet Neurol 2013;12:609-622.

83. Rapoport M, Ferreira A. PD98059 prevents neurite degeneration induced by fibrillar beta-amyloid in mature hippocampal neurons. $\mathrm{J}$ Neurochem 2000;74:125-133.

84. Greenberg SM, Koo EH, Selkoe DJ, Qiu WQ, Kosik KS. Secreted beta-amyloid precursor protein stimulates mitogen-activated protein kinase and enhances tau phosphorylation. Proc Natl Acad Sci U S A 1994;91:7104-7108.

85. Desdouits-Magnen J, Desdouits F, Takeda S et al. Regulation of secretion of Alzheimer amyloid precursor protein by the mitogenactivated protein kinase cascade. J Neurochem 1998;70:524-530.

86. Mills J, Laurent Charest D, Lam F et al. Regulation of amyloid precursor protein catabolism involves the mitogen-activated protein kinase signal transduction pathway. J Neurosci 1997;17: 9415-9422.

87. Kim SK, Park HJ, Hong HS, Baik EJ, Jung MW, Mook-Jung I. ERK $1 / 2$ is an endogenous negative regulator of the gammasecretase activity. FASEB J 2006;20:157-159.

88. Tung YT, Hsu WM, Wang BJ et al. Sodium selenite inhibits gamma-secretase activity through activation of ERK. Neurosci Lett 2008;440:38-43.

89. Wan X-Z, Li B, Li Y-C et al. Activation of NMDA receptors upregulates a disintegrin and metalloproteinase 10 via a Wnt/ MAPK signaling pathway. J Neurosci 2012;32:3910-3916.

90. Kojro E, Postina R, Buro C, Meiringer C, Gehrig-Burger K, Fahrenholz F. The neuropeptide PACAP promotes the alphasecretase pathway for processing the Alzheimer amyloid precursor protein. FASEB J 2006;20:512-514.

91. Mitsuda N, Ohkubo N, Tamatani M et al. Activated cAMP-response element-binding protein regulates neuronal expression of presenilin-1. J Biol Chem 2001;276:9688-9698.

92. Hardingham N, Dachtler J, Fox K. The role of nitric oxide in presynaptic plasticity and homeostasis. Front Cell Neurosci 2013;7:190.

93. Puzzo D, Palmeri A, Arancio O. Involvement of the nitric oxide pathway in synaptic dysfunction following amyloid elevation in Alzheimer's disease. Rev Neurosci 2006; 17:497-523.

94. Lu YF, Kandel ER, Hawkins RD. Nitric oxide signaling contributes to late-phase LTP and CREB phosphorylation in the hippocampus. J Neurosci 1999;19:10250-10261.

95. Wong JC, Bathina M, Fiscus RR. Cyclic GMP/protein kinase G type-Ialpha (PKG-Ialpha) signaling pathway promotes CREB phosphorylation and maintains higher c-IAP1, livin, survivin, and Mcl-1 expression and the inhibition of PKG-Ialpha kinase activity synergizes with cisplatin in non-small cell lung cancer cells. J Cell Biochem 2012;113:3587-3598.

96. Riccio A, Alvania RS, Lonze BE, et al. A nitric oxide signaling pathway controls CREB-mediated gene expression in neurons. Mol Cell 2006;21:283-294.

97. Bernabeu R, Schmitz P, Faillace MP, Izquierdo I, Medina JH. Hippocampal cGMP and cAMP are differentially involved in 
memory processing of inhibitory avoidance learning. Neuroreport 1996;7:585-588.

98. Matsumoto Y, Unoki S, Aonuma H, Mizunami M. Critical role of nitric oxide-cGMP cascade in the formation of cAMP-dependent long-term memory. Learn Mem 2006;13:35-44.

99. Rutten K, Prickaerts J, Hendrix M, van der Staay FJ, Sik A, Blokland A. Time-dependent involvement of cAMP and cGMP in consolidation of object memory: studies using selective phosphodiesterase type 2, 4 and 5 inhibitors. Eur J Pharmacol 2007;558:107-112.

100. Bollen E, Puzzo D, Rutten K, et al. Improved long-term memory via enhancing cGMP-PKG signaling requires cAMP-PKA signaling. Neuropsychopharmacology 2014;39:2497-2505.

101. Hu SC, Chrivia J, Ghosh A. Regulation of CBP-mediated transcription by neuronal calcium signaling. Neuron 1999;22:799-808.

102. Montminy M. Transcriptional regulation by cyclic AMP. Annu Rev Biochem 1997;66:807-822.

103. Tao X, Finkbeiner S, Arnold DB, Shaywitz AJ, Greenberg ME. $\mathrm{Ca} 2+$ influx regulates BDNF transcription by a CREB family transcription factor-dependent mechanism. Neuron 1998;20:709-726.

104. Murphy DD, Segal M. Morphological plasticity of dendritic spines in central neurons is mediated by activation of cAMP response element binding protein. Proc Natl Acad Sci U S A 1997;94:1482-1487.

105. Paris D, Town T, Parker TA, et al. Inhibition of Alzheimer's betaamyloid induced vasoactivity and proinflammatory response in microglia by a cGMP-dependent mechanism. Exp Neurol 1999;157:211-221.

106. McCarty MF. Vascular nitric oxide may lessen Alzheimer's risk. Med Hypotheses 1998;51:465-476.

107. Suhara T, Magrane J, Rosen K, et al. Abeta42 generation is toxic to endothelial cells and inhibits eNOS function through an Akt/GSK-3beta signaling-dependent mechanism. Neurobiol Aging 2003;24:437-451.

108. Venturini G, Colasanti M, Persichini T, et al. Beta-amyloid inhibits NOS activity by subtracting NADPH availability. FASEB J 2002; 16:1970-1972.

109. Baltrons MA, Pedraza CE, Heneka MT, Garcia A. Beta-amyloid peptides decrease soluble guanylyl cyclase expression in astroglial cells. Neurobiol Dis 2002;10:139-149.

110. Puzzo D, Vitolo O, Trinchese F, Jacob JP, Palmeri A, Arancio O. Amyloid-beta peptide inhibits activation of the nitric oxide/cGMP/ cAMP-responsive element-binding protein pathway during hippocampal synaptic plasticity. J Neurosci 2005;25:6887-6897.

111. Miller TW, Isenberg JS, Shih HB, Wang Y, Robert DD. Amyloidbeta inhibits No-cGMP signaling in a CD36- and CD47-dependent manner. PLoS One 2010;5:e15686.

112. Puzzo D, Staniszewski A, Deng SX, et al. Phosphodiesterase 5 inhibition improves synaptic function, memory, and amyloid-beta load in an Alzheimer's disease mouse model. J Neurosci 2009;29:8075-8086.

113. Palmeri A, Privitera L, Giunta S, Loreto C, Puzzo D. Inhibition of phosphodiesterase-5 rescues age-related impairment of synaptic plasticity and memory. Behav Brain Res 2013;240:11-20.

114. Wirtz-Brugger F, Giovanni A. Guanosine 3',5'-cyclic monophosphate mediated inhibition of cell death induced by nerve growth factor withdrawal and beta-amyloid: protective effects of propentofylline. Neuroscience 2000;99:737-750.

115. Bonkale WL, Winblad B, Ravid R, Cowburn RF. Reduced nitric oxide responsive soluble guanylyl cyclase activity in the superior temporal cortex of patients with Alzheimer's disease. Neurosci Lett 1995; 187:5-8.

116. Ciani E, Guidi S, Bartesaghi R, Contestabile A. Nitric oxide regulates cGMP-dependent cAMP-responsive element binding protein phosphorylation and Bcl-2 expression in cerebellar neurons: implication for a survival role of nitric oxide. J Neurochem 2002;82:1282-1289.

117. Gudi T, Casteel DE, Vinson C, Boss GR, Pilz RB. NO activation of fos promoter elements requires nuclear translocation of G-kinase I and CREB phosphorylation but is independent of MAP kinase activation. Oncogene 2000;19:6324-6333.
118. Tong L, Thornton PL, Balazs R, Cotman CW. Beta -amyloid-(1-42) impairs activity-dependent cAMP-response element-binding protein signaling in neurons at concentrations in which cell survival Is not compromised. J Biol Chem 2001;276:17301-17306.

119. Samengo G, Avik A, Fedor B, et al. Age-related loss of nitric oxide synthase in skeletal muscle causes reductions in calpain $\mathrm{S}$ nitrosylation that increase myofibril degradation and sarcopenia. Aging Cell 2012;11:1036-1045.

120. Domek-Lopacinska KU, Strosznajder JB. Cyclic GMP and nitric oxide synthase in aging and Alzheimer's disease. Mol Neurobiol 2010;41:129-137.

121. Law A, O'Donnell J, Gauthier S, Quirion R. Neuronal and inducible nitric oxide synthase expressions and activities in the hippocampi and cortices of young adult, aged cognitively unimpaired, and impaired Long-Evans rats. Neuroscience 2002;112:267-275.

122. Schrage WG, Eisenach JH, Joyner MJ. Ageing reduces nitric-oxideand prostaglandin-mediated vasodilatation in exercising humans. $\mathrm{J}$ Physiol 2007;579:227-236.

123. Burgaud JL, Riffaud JP, Del Soldato P. Nitric-oxide releasing molecules: a new class of drugs with several major indications. Curr Pharm Des 2002;8:201-213.

124. Jantzen PT, Connor KE, DiCarlo G, et al. Microglial activation and beta -amyloid deposit reduction caused by a nitric oxide-releasing nonsteroidal anti-inflammatory drug in amyloid precursor protein plus presenilin-1 transgenic mice. J Neurosci 2002;22:2246-2254.

125. Thatcher GR, Bennett BM, Dringenberg HC, Reynolds JN. Novel nitrates as NO mimetics directed at Alzheimer's disease. J Alzheimers Dis 2004;6(6 Suppl.):S75-S84.

126. Thatcher GR, Bennett BM, Reynolds JN. Nitric oxide mimetic molecules as therapeutic agents in Alzheimer's disease. Curr Alzheimer Res 2005;2:171-182.

127. Wenk GL, McGann-Gramling K, Hauss-Wegrzyniak B, et al. Attenuation of chronic neuroinflammation by a nitric oxidereleasing derivative of the antioxidant ferulic acid. J Neurochem. 2004;89:484-493.

128. Fiorito J, Saeed F, Zhang H, et al. Synthesis of quinoline derivatives: discovery of a potent and selective phosphodiesterase 5 inhibitor for the treatment of Alzheimer's disease. Eur J Med Chem 2013; 60:285-294.

129. Puzzo D, Loreto C, Giunta S, et al. Effect of phosphodiesterase-5 inhibition on apoptosis and beta amyloid load in aged mice. Neurobiol Aging 2014;35:520-531.

130. Goll DE, Thompson VF, Li H, Wei W, Cong J. The calpain system. Physiol Rev 2003;83:731-801.

131. Sorimachi $\mathrm{H}$, Hata $\mathrm{S}$, Ono $\mathrm{Y}$. Impact of genetic insights into calpain biology. J Biochem 2011;150:23-37.

132. Wu HY, Lynch DR. Calpain and synaptic function. Mol Neurobiol 2006;33:215-236

133. Baudry M, Chou MM, Bi X. Targeting calpain in synaptic plasticity. Expert Opin Ther Targets 2013;17:579-592.

134. Cong J, Goll DE, Peterson AM, Kapprell HP. The role of autolysis in activity of the $\mathrm{Ca} 2+$-dependent proteinases (mu-calpain and $\mathrm{m}$ calpain). J Biol Chem 1989;264:10096-10103.

135. Liu F, Grundke-Iqbal I, Iqbal K, Oda Y, Tomizawa K, Gong CX. Truncation and activation of calcineurin A by calpain I in Alzheimer disease brain. J Biol Chem 2005;280:37755-37762.

136. Saito K, Elce JS, Hamos JE, Nixon RA. Widespread activation of calcium-activated neutral proteinase (calpain) in the brain in Alzheimer disease: a potential molecular basis for neuronal degeneration. Proc Natl Acad Sci U S A 1993;90:2628-2632.

137. Hu GY, Hvalby O, Walaas SI, et al. Protein kinase C injection into hippocampal pyramidal cells elicits features of long term potentiation. Nature 1987;328:426-429.

138. Lledo, PM, Hjelmstad GO, Mukherji S, Soderling TR, Malenka RC, Nicoll RA. Calcium/calmodulin-dependent kinase II and longterm potentiation enhance synaptic transmission by the same mechanism. Proc Natl Acad Sci U S A 1995;92:11175-11179. 
139. Malinow R, Schulman H, Tsien RW. Inhibition of postsynaptic PKC or CaMKII blocks induction but not expression of LTP. Science 1989;245:862-826.

140. Otmakhov N, Griffith LC, Lisman JE. Postsynaptic inhibitors of calcium/calmodulin-dependent protein kinase type II block induction but not maintenance of pairing-induced long-term potentiation. J Neurosci 1997; 17:5357-5365.

141. Hajimohammadreza I, Raser KJ, Nath R, Nadimpalli R, Scott M, Wang KK. Neuronal nitric oxide synthase and calmodulindependent protein kinase IIalpha undergo neurotoxin-induced proteolysis. J Neurochem 1997;69:1006-1013.

142. Hrabetova S, Sacktor TC. Bidirectional regulation of protein kinase $\mathrm{M}$ zeta in the maintenance of long-term potentiation and long-term depression. J Neurosci 1996; 16:5324-5233.

143. Wu HY, Tomizawa K, Oda Y, et al. Critical role of calpain-mediated cleavage of calcineurin in excitotoxic neurodegeneration. J Biol Chem 2004;279:4929-4940

144. Watt F, Molloy PL. Specific cleavage of transcription factors by the thiol protease, m-calpain. Nucleic Acids Res 1993;21:5092-100.

145. Jin N, Qian W, Yin X, et al. CREB regulates the expression of neuronal glucose transporter 3: a possible mechanism related to impaired brain glucose uptake in Alzheimer's disease. Nucleic Acids Res 2013;41: 3240-3256.

146. Wu X, Spiro C, Owen WG, McMurray CT. cAMP response element-binding protein monomers cooperatively assemble to form dimers on DNA. J Biol Chem 1998;273:20820-20827.

147. Ferreira A, Bigio EH. Calpain-mediated tau cleavage: a mechanism leading to neurodegeneration shared by multiple tauopathies. Mol Med 2011;17:676-685.

148. Higuchi M, Tomioka M, Takano J, et al. Distinct mechanistic roles of calpain and caspase activation in neurodegeneration as revealed in mice overexpressing their specific inhibitors. J Biol Chem 2005;280:15229-15237.

149. Patrick GN, Zukerberg L, Nikolic M, de la Monte S, Dikkes P, Tsai LH. Conversion of p35 to p25 deregulates Cdk5 activity and promotes neurodegeneration. Nature 1999;402:615-622.

150. Peterson C, Goldman JE. Alterations in calcium content and biochemical processes in cultured skin fibroblasts from aged and Alzheimer donors. Proc Natl Acad Sci U S A 1986;83:2758-2762.

151. Saitoh T, Masliah E, Jin LW, Cole GM, Wieloch T, Shapiro IP. Protein kinases and phosphorylation in neurologic disorders and cell death. Lab Invest 1991;64:596-616.

152. Tsuji T, Shimohama S, Kimura J, Shimizu K. m-Calpain (calciumactivated neutral proteinase) in Alzheimer's disease brains. Neurosci Lett 1998;248:109-112.

153. Vosler PS, Brennan CS, Chen J. Calpain-mediated signaling mechanisms in neuronal injury and neurodegeneration. Mol Neurobiol 2008;38:78-100.

154. Trinchese F, Fa M, Liu S, et al. Inhibition of calpains improves memory and synaptic transmission in a mouse model of Alzheimer disease. J Clin Invest 2008;118:2796-2807.

155. Di Rosa G, Odrijin T, Nixon RA, Arancio O. Calpain inhibitors: a treatment for Alzheimer's disease. J Mol Neurosci 2002;19:135-141.

156. Toth E, Bruin JP, Heinsbroek RP, Joosten RN. Spatial learning and memory in calpastatin-deficient rats. Neurobiol Learn Mem 1996;66:230-235.

157. Liang Z, Liu F, Grundke-Iqbal I, Iqbal K, Gong CX. Down-regulation of cAMP-dependent protein kinase by over-activated calpain in Alzheimer disease brain. J Neurochem 2007;103:2462-2470.

158. Masliah E, Mallory M, Hansen L, DeTeresa R, Alford M, Terry R. Synaptic and neuritic alterations during the progression of Alzheimer's disease. Neurosci Lett 1994;174:67-72.

159. Sheng M, Sabatini BL, Sudhof TC. Synapses and Alzheimer's disease. Cold Spring Harb Perspect Biol 2012;4(5): a005777.

160. Ferreira A. Calpain Dysregulation in Alzheimer's Disease. ISRN Biochemistry 2012;12. doi:10.5402/2012/728571
161. Liang B, Duan BY, Zhou XP, Gong JX, Luo ZG. Calpain activation promotes BACE1 expression, amyloid precursor protein processing, and amyloid plaque formation in a transgenic mouse model of Alzheimer disease. J Biol Chem 2010;285:27737-27744.

162. Grynspan F, Griffin WR, Cataldo A, Katayama S, Nixon RA. Active site-directed antibodies identify calpain II as an earlyappearing and pervasive component of neurofibrillary pathology in Alzheimer's disease. Brain Res 1997;763:145-158.

163. Seo J, Giusti-Rodriguez P, Zhou Y, et al. Activity-dependent p25 generation regulates synaptic plasticity and Abeta-induced cognitive impairment. Cell 2014;157:486-498.

164. Higuchi M, Iwata N, Matsuba Y, et al. Mechanistic involvement of the calpain-calpastatin system in Alzheimer neuropathology. FASEB J 2012;26:1204-1217.

165. Donkor IO. Calpain inhibitors: a survey of compounds reported in the patent and scientific literature. Expert Opin Ther Pat 2011;21:601-636.

166. Pietsch M, Chua KC, Abell AD. Calpains: attractive targets for the development of synthetic inhibitors. Curr Top Med Chem 2010;10: 270-293.

167. Hanada K, Tamai M, Yamagishi M, Ohmura S, Sawada J, Tanaka I. Isolation and Characterization of E-64, a New Thiol Protease Inhibitor. Agricultural and Biological Chemistry 1978;42:523-528.

168. Parkes C, Kembhavi AA, Barrett AJ. Calpain Inhibition by Peptide Epoxides. Biochemical Journal 1985;230:509-516.

169. Sugita H, Ishiura S, Suzuki K, Imahori K. Inhibition of Epoxide Derivatives on Chicken Calcium-Activated Neutral Protease (Canp) Invitro and Invivo. Journal of Biochemistry 1980;87:339-341.

170. Battaglia F, Trinchese F, Liu SM, Walter S, Nixon RA, Arancio O. Calpain inhibitors, a treatment for Alzheimer's disease - Position paper. Journal of Molecular Neuroscience 2003;20:357-362.

171. Schiefer IT, Tapadar S, Litosh V, et al. Design, Synthesis, and Optimization of Novel Epoxide Incorporating Peptidomimetics as Selective Calpain Inhibitors. Journal of Medicinal Chemistry 2013;56:6054-6068.

172. Citron M, Diehl TS, Gordon G, Biere AL, Seubert P, Selkoe DJ. Evidence that the 42- and 40-amino acid forms of amyloid beta protein are generated from the beta-amyloid precursor protein by different protease activities. Proc Natl Acad Sci U S A 1996;93:13170-13175.

173. Higaki J, Quon D, Zhong Z, Cordell B. Inhibition of beta-amyloid formation identifies proteolytic precursors and subcellular site of catabolism. Neuron 1995;14:651-659.

174. Nikkel AL, Martino B, Markosyan S, et al. The novel calpain inhibitor A-705253 prevents stress-induced tau hyperphosphorylation in vitro and in vivo. Neuropharmacology 2012;63:606-612.

175. Sinjoanu RC, Kleinschmidt S, Bitner RS, Brioni JD, Moeller A, Ferreira A. The novel calpain inhibitor A-705253 potently inhibits oligomeric beta-amyloid-induced dynamin 1 and tau cleavage in hippocampal neurons. Neurochemistry International 2008;53:79-88.

176. Medeiros R, Kitazawa M, Chabrier MA, et al. Calpain Inhibitor A705253 Mitigates Alzheimer's Disease-Like Pathology and Cognitive Decline in Aged 3xTgAD Mice. American Journal of Pathology 2012;181:616-625.

177. Schneider A, Chatterjee S, Bousiges O, et al. Acetyltransferases (HATs) as targets for neurological therapeutics. Neurotherapeutics 2013;10:568-588.

178. Bolden JE, Peart MJ, Johnstone RW. Anticancer activities of histone deacetylase inhibitors. Nat Rev Drug Discov 2006;5: 769-784

179. Fischer A, Sananbenesi F, Wang X, Dobbin M, Tsai LH, et al. Recovery of learning and memory is associated with chromatin remodelling. Nature 2007;447:178-182.

180. Fontán-Lozano A, Romero-Granados R, Troncoso J, Múnera A, Delgado-García JM, Carrión AM. Histone deacetylase inhibitors improve learning consolidation in young and in KA-inducedneurodegeneration and SAMP-8-mutant mice. Mol Cell Neurosci 2008;39:193-201. 
181. Hawk JD, Abel T. The role of NR4A transcription factors in memory formation. Brain Res Bull 2011;85:21-29.

182. Perez-Cadahia B, Drobic B, Davie JR. Activation and function of immediate-early genes in the nervous system. Biochem Cell Biol 2011;89:61-73.

183. Dragunow M. A role for immediate-early transcription factors in learning and memory. Behav Genet 1996;26:293-299.

184. Vecsey CG, Hawk JD, Lattal KM, et al. Histone deacetylase inhibitors enhance memory and synaptic plasticity via CREB: CBP-dependent transcriptional activation. J Neurosci 2007;27: 6128-6140.

185. Stilling RM, Fischer A. The role of histone acetylation in ageassociated memory impairment and Alzheimer's disease. Neurobiol Learn Mem 2011;96:19-26.

186. Francis YI, Fà M, Ashraf H, et al. Dysregulation of histone acetylation in the APP/PS1 mouse model of Alzheimer's disease. $J$ Alzheimers Dis 2009;18:131-139.

187. Stefanko DP, Barrett RM, Ly AR, Reolon GK, Wood MA. Modulation of long-term memory for object recognition via HDAC inhibition. Proc Natl Acad Sci U S A 2009;106:9447-9452.

188. Ricobaraza A, Cuadrado-Tejedor M, Pérez-Mediavilla A, Frechilla D, Del Río J, García-Osta A. Phenylbutyrate ameliorates cognitive deficit and reduces tau pathology in an Alzheimer's disease mouse model. Neuropsychopharmacology 2009;34:1721-1732.

189. Oliveira AM, Wood MA, McDonough CB, Abel T. Transgenic mice expressing an inhibitory truncated form of p300 exhibit long-term memory deficits. Learn Mem 2007;14:564-572.

190. Maurice T, Duclot F, Meunier J, et al. Altered memory capacities and response to stress in $\mathrm{p} 300 / \mathrm{CBP}$-associated factor (PCAF) histone acetylase knockout mice. Neuropsychopharmacology 2008;33:1584-1602.

191. Wei W, Coelho CM, Li X, et al. p300/CBP-associated factor selectively regulates the extinction of conditioned fear. J Neurosci 2012;32:11930-11941.

192. Chatterjee S1, Mizar P, Cassel R, et al. A novel activator of CBP/ p300 acetyltransferases promotes neurogenesis and extends memory duration in adult mice. J Neurosci 2013;33:10698-10712.

193. Wu J, Anwyl R, Rowan MJ. beta-Amyloid-(1-40) increases longterm potentiation in rat hippocampus in vitro. Eur $\mathrm{J}$ Pharmacol 1995;284:R1-R3.

194. Kowalska MA, Badellino K. beta-Amyloid protein induces platelet aggregation and supports platelet adhesion. Biochem Biophys Res Commun 1994;205:1829-1835.

195. Mattson MP, Guo ZH, Geiger JD. Secreted form of amyloid precursor protein enhances basal glucose and glutamate transport and protects against oxidative impairment of glucose and glutamate transport in synaptosomes by a cyclic GMP-mediated mechanism. J Neurochem 1999;73:532-537.

196. Puzzo D, Privitera L, Palmeri A. Hormetic effect of amyloid-beta peptide in synaptic plasticity and memory. Neurobiol Aging 2012;33:1484 e15-24.

197. Puzzo D, Arancio O. Amyloid-beta peptide: Dr. Jekyll or Mr. Hyde? J Alzheimers Dis 2013;33:(Suppl. 1): S111-S120.

198. Barco A, Pittenger C, Kandel ER. CREB, memory enhancement and the treatment of memory disorders: promises, pitfalls and prospects. Expert Opin Ther Targets 2003;7:101-114.

199. Cho EC, Mitton B, Sakamoto KM. CREB and leukemogenesis. Crit Rev Oncog 2011;16:37-46. 